\title{
An Environmental Domain Classification of Canada using Earth Observation data for Biodiversity Assessment
}

Nicholas C. Coops ${ }^{1^{*}}$, Michael A. Wulder ${ }^{2}$, Donald Iwanicka ${ }^{3}$

1- Department of Forest Resource Management, 2424 Main Mall, University of British Columbia, Vancouver, British Columbia, V6T 1Z4, Canada

2-Canadian Forest Service (Pacific Forestry Center), Natural Resources Canada, Victoria, British Columbia, V8Z 1M5, Canada

3-Department of Forest Resource Management, 2424 Main Mall, University of British Columbia, Vancouver, British Columbia, V6T 1Z4, Canada

$\left.{ }^{*}\right)$ corresponding author:

Nicholas C. Coops:

Phone: (604) 822 6452; Fax (604) 822-9106; Email: nicholas.coops@ubc.ca

\section{Pre-print of published version.}

\section{Reference:}

Coops, N.C., Wulder, M.A., Iwanicka, D. (2009) An Environmental Domain Classification of Canada using Earth Observation data for Biodiversity Assessment Ecological Infomatics. 4: 8-22.

\section{DOI:}

doi:10.1016/j.ecoinf.2008.09.005

\section{Disclaimer:}

The PDF document is a copy of the final version of this manuscript that was subsequently accepted by the journal for publication. The paper has been through peer review, but it has not been subject to any additional copy-editing or journal specific formatting (so will look different from the final version of record, which may be accessed following the DOI above depending on your access situation). 


\section{ABSTRACT}

Broad ecosystem based classifications are increasingly applied as a context to consider, understand, and manage biodiversity. The need for more spatially explicit, repeatable, transferable, transparent, and defensible environmental regionalization has become apparent. Increased computing power, sophisticated analysis software, and the availability of spatially explicit descriptions of the environment, principally derived from Earth observation data, has facilitated the development of statistical ecosystem regionalizations. These regionalizations are desired to produce environmentally unique ecoregions to provide the basis for stratification for ongoing biodiversity monitoring efforts. Using a suite of indicators of the physical environment, available energy such as vegetation production, and habitat suitability all derived from remote sensing technology at $1 \mathrm{~km}$ spatial resolution, we undertook a environmental regionalization using a twostage multivariate classification of terrestrial Canada. A relatively large number of classes was initially derived (100) and a hierarchical clustering approach was then applied to derive a 40 level classification. These clusters where then used to assess which clusters were the most dissimilar to the majority thus providing indication of the most unique environmental domains across Canada. Secondly, a 14 class stratification was then produced to emulate the current ecozone stratification commonly used in Canada. Results indicated that a number of unique clusters exits across Canada, specifically the forest/urban-industrial/cropland mosaic in the southern portion of Ontario, the mixed wood forests in south-central Ontario and western Quebec, the foothills of south western Alberta, regions of the southern Arctic and the northern Boreal shield (particularly the areas south of Hudson Bay and Labrador). A resemblance between the 14 class stratification and the ecozone classification for Canada is evident; locations of within and between ecozone heterogeneity are also indicated. A critical key benefit of utilising ecoregions quantitatively using key indicators, such as those derived from remote sensing observations, is the capacity to establish, and quantify, how well particular networks of sites, or plot locations, represent the overall environment. As such, the incorporation of these types of methods, and remotely derived indicators, into biodiversity assessment is an important area of ongoing research. 
Key words: Ecosystem classification, Ecozone, decision tree, MODIS, cluster, Canada 


\section{INTRODUCTION}

Ecosystem based approaches to the management of biodiversity within the broader terrestrial and aquatic environment are becoming increasing utilised tools for sustainable management (Christensen et al., 1996, Leathwick et al., 2003). Critical for success is the underlying classification that identifies geographic areas with similar ecological features or characteristics (Leathwick et al., 2003). These individual groupings, often labelled clusters, ecoregions or ecozones, provide an underlying basis for systematic conservation and management over large areas principally including the assignment of biodiversity values based on the characteristics of the natural ecosystems (Pressey et al., 2004), setting ongoing priorities for conservation and protection (Metrick and Weitzman, 1998), and identifying areas which are undergoing unusual perturbations where management action may be required.

The definition of these clusters, or ecoregions, and the boundaries that delineate them in time and space, is inherently difficult with ongoing discussion as to the optimum developmental approach. Issues such as whether the stratifications should be undertaken for specific applications or promote general purpose applications, whether the resulting clusters are spatially contiguous as opposed to disjointed, nestable or nonhierarchical clusters, and if the derived stratification units can subsequently form the basis for management (Omernik 1995; Omernik, 2003; Hargrove and Hoffman, 2005).

Historically, the process of developing and delineating ecoregions, a process known as regionalization (Hargrove and Hoffman, 1999), has been subjective with a number of experts integrating a wide range of environmental characteristics, and applying a weight-of-evidence approach (McMahon et al., 2001). As a result, the derived ecoregions are subjective, and often subject to ongoing revision and discussion over particular locations (Hargrove and Hoffman, 1999). As such, the acceptance of ecosystem classifications by resource managers is largely dependent on their information needs to meet a particular suite of management objectives (Noss, 1996). 
With increases in computing power, and the availability of spatially explicit descriptions of the environment and its biota (Leathwick et al., 2003), the potential to develop quantitative rather than qualitative models has increased significantly in the past decade with quantitative regionalization models more explicit, repeatable, transferable, and defensible than subjective models based on human expertise (Lugo et al., 1999). These characteristics, we consider, enhance and expand the utility of ecoregions and provide an indispensable component for ecosystem management, allowing areas of common environmental characteristics to be grouped, dissimilar classes compared, as well as quantitative analysis of how unique locations are, and their subsequent role in ongoing monitoring programs.

In this paper, we present the results of an environmental clustering classification of Canada's terrestrial land base using a number of factors which have been shown to be relevant as indirect indicators of biodiversity. The input factors have all been derived from Earth observation data and include satellite derived measures of productivity, topography, and land cover. The overall goal is the production of ecoregion regionalizations to enable the development of tools to provide meaningful spatial context for monitoring, to capture the dynamics of an ecoregion, and to aid in considerations of biodiversity at a national level; whereby, a national early warning system, indicating where areas of potential biodiversity change may be occurring. The objectives of this paper are to present the needs and options for quantitative ecosystem regionalization, definition of a recommended approach, application, and subsequent investigation of the nature and utility of the derived clusters. Key questions are addressed to explore and understand the uniqueness of the regionalizations developed and the utility of the regionalizations as a context for Canada-wide ecological and biodiversity monitoring purposes.

\section{BACKGROUND}

\subsection{Quantitative methods for ecoregion characterisation}

A wide range of quantitative methods exist for ecosystem definition (see review by Hargrove and Hoffman (2005)) with the development of quantitative methods principally 
driven by the need to map the geographic range of a single species of animal or plant (Hargrove and Hoffman, 2005), a range of assemblages, or more general regional clustering to form homogeneous regions. These approaches vary based on whether they are designed to map domains of a single species or for wider area mapping of species assemblages or types. One of the earliest attempts at classifying ecosystems based on explicit environmental layers was undertaken by Holdridge (1947), who developed the Holdridge Life Zone model which utilised data on growing season length and temperature, mean annual precipitation which is combined with potential evapotranspiration to stratify terrestrial environments. More recently, multivariate classification techniques have been applied directly to suites of environmental layers with this approach generally referred to as environmental domains with many papers on differing statistical methods (Belbin, 1993; Faith et al., 2001), methodologies (Mackey et al., 1988; Hargrove \& Hoffman, 1999), and applications (Leathwick et al., 2003). As discussed by Hargrove \& Hoffman, (1999), for single species approaches, a range of multivariate techniques including generalised linear and additive models (Austin et al., 1990; Overton et al., 2000; Leathwick, 2001), Classification and Regression Trees (CART) (Stoms and Hargrove, 2000), and geographic range prediction (Iverson et al., 1999) have successfully been applied. In addition, a number of software packages have been specifically developed which apply envelope-based methods to capture environmental variation (Busby 1991, Walker and Cocks 1991) which form envelopes around clusters of cells with similar environmental conditions.

Rather than defining the environmental domain around a single species, an alternative approach is multivariate clustering which delineates regions of homogeneity objectively using a series of input spatial layers (Host et al.,1996). These clustering approaches are statistical in nature allowing derivation of both sub- and super-groups based on similarity. Host et al. (1996) applied clustering approaches to establish a range of climatic and physiographic regions for northern Wisconsin, USA. Soriano and Paruelo (1992) applied a normalized multidimensional ordination of remotely sensed imagery to form clusters for Argentinian Patagonia. More recently, Leathwick et al. (2003) created a suite of environmental domains at $1 \mathrm{~km}$ spatial resolution for New Zealand using a two- 
stage multivariate classification derived from 10 climatic and landform variables, with the Gower metric as the statistical similarity measure (Hirzel and Arlettaz, 2003).

In this paper we utilise a suite of indicators of the physical environment, available energy through indices of vegetation production, and habitat suitability, all derived from remote sensing technology at $1 \mathrm{~km}$ spatial resolution, and undertake an environmental regionalization using a two-stage multivariate classification approach. First we develop a cluster classification with a relatively large number of initial classes and a hierarchical clustering approach applied initially. These clusters where then used to assess which clusters were the most dissimilar to the majority thus providing indication of the most unique environmental domains across Canada. Our second analysis involved a 14 class stratification to emulate the current ecozone stratification commonly used in Canada allowing the comparison of within and between ecozone heterogeneity.

\section{METHODS}

\subsection{Study area}

Canada's land mass is approximately 10 million $\mathrm{km}^{2}$, characterized by a wide range of topographic, climatic, and ecological variation. Topographic changes found across Canada are the most dramatic in the mountainous western regions, with topography flattening eastward, with less significant regional variation across the prairie, boreal and arctic regions. Eastern and Atlantic Canada topography, in contrast, is typified by gentle terrain changes primarily resulting from the last glaciation. Variations in temperature and precipitation are driven by both regional and continental influences, with precipitation across the arctic, boreal, and prairie regions low to moderate, with wetter regimes on the east and west coasts. The annual temperature gradient across Canada reflects hot continental summers with extremely cold winters, with temperatures generally decreasing when moving northward in latitude. The Pacific and Atlantic coastal regions have cooler summers and warmer winters than the interior. 


\subsection{Data}

Vegetation of the land surface provides a critical and sensitive indicator of the climate and topography (Bailey et al., 1985). As a result, researchers often construct ecozone characterisations of vegetation growth patterns and species groupings (Lieth, 1975). As the direct estimation of vegetation composition and function over the landscape is often impossible and inaccurate due to the scarcity of data on climate, vegetation, and soil, remotely sensed data is often utilised to overcome, for instance, limitations in data availability, spatial extent, and information currency.

In a recent review of the potential of remote sensing technology to provide factors, or explanatory indicators, understood to be related biodiversity present over large areas, Duro et al. (2007) proposed broad categories which capture previous and current research trends. Of the categories defined and explored in the review, three measures described in detail below are particularly relevant to this application: (i) the physical environment, such as topography and land cover, (ii) indicators of available energy such as vegetation production, productivity, or function, and (iii) habitat suitability, with respect to its spatial arrangement and structure. These three spatial layers are shown in Figures 1(a)-(c), and for reference the existing 14 class ecozones are shown in Figure $1(d)$.
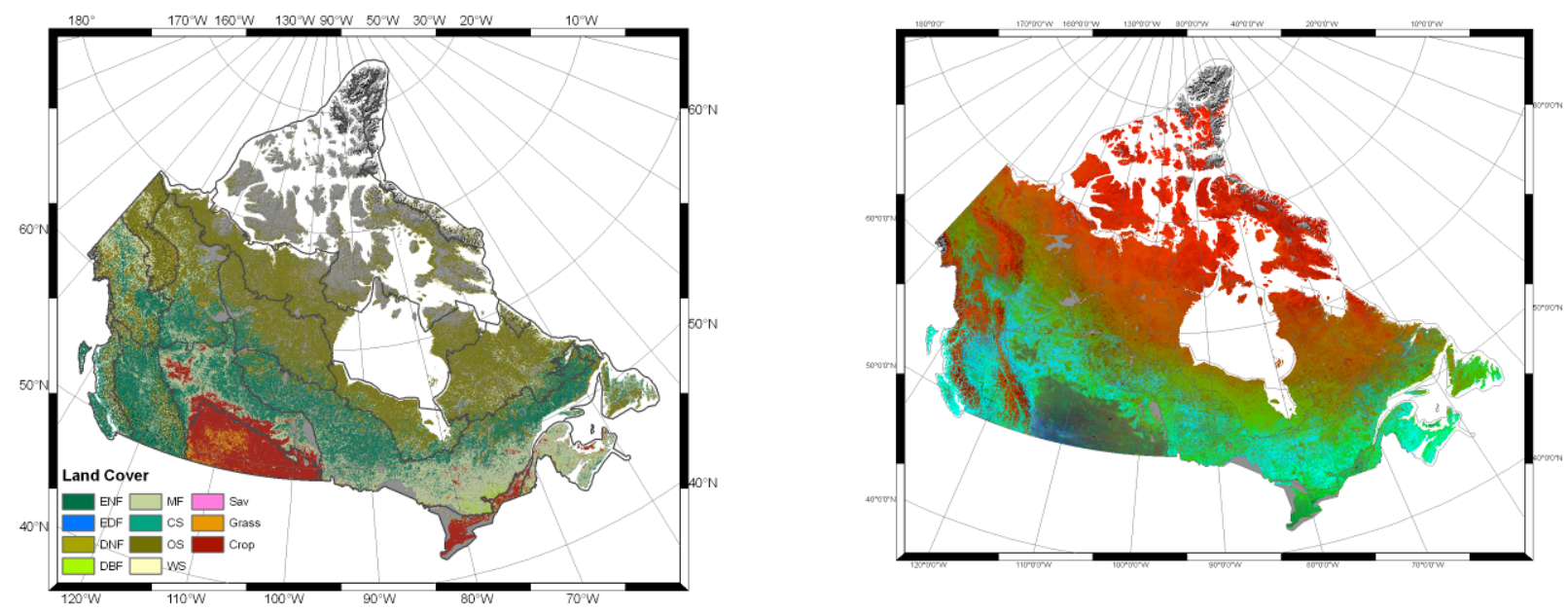

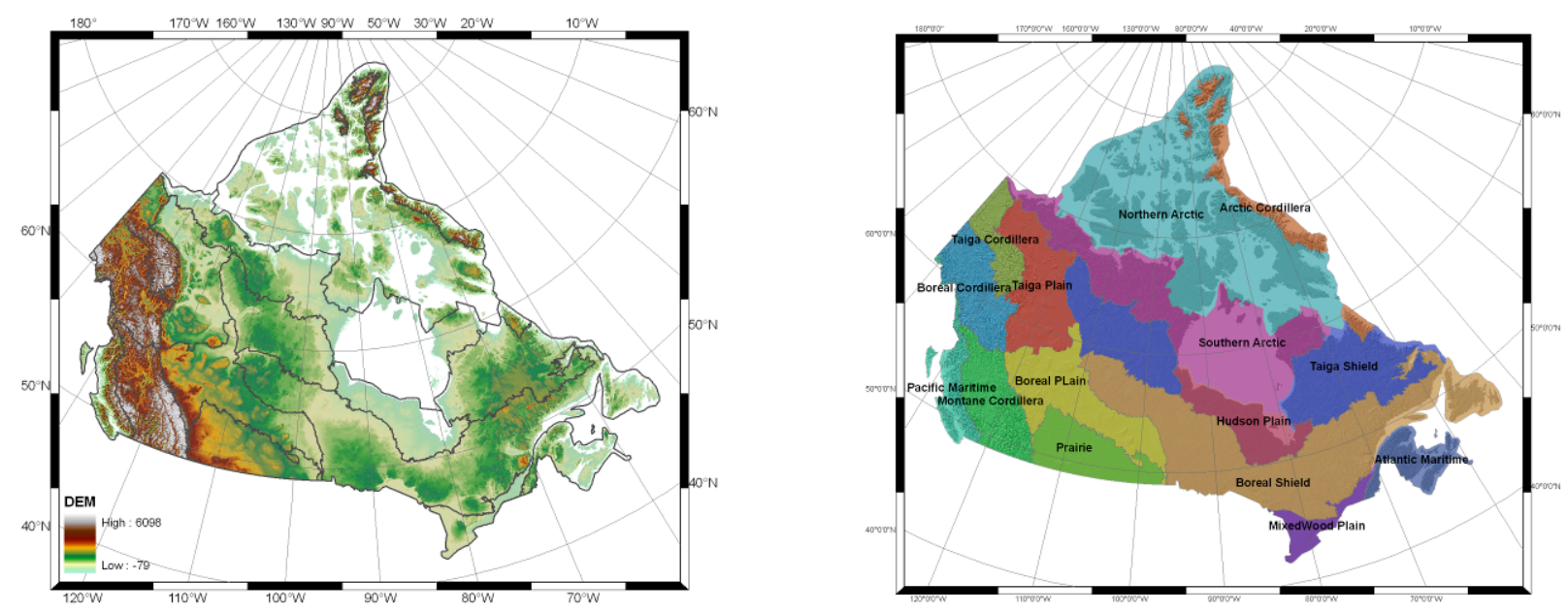

Figure 1 (a)-(d): The three remotely sensed indicators used in the regionalization (a) Land cover, (b) the Dynamic Habitat Index (DHI) and (C) terrain. Figure 1(d) shows the existing 14 class ecozones derived by Environment Canada for reference.

\subsection{Topography}

While elevation is a relatively static variable compared to other biophysical factors (e.g., climate), its function as a key biodiversity driver has been well documented (Rosenzweig, 1995). For example, in the tropics, curvi-linear relationships have been proposed with species diversity, with higher species diversity occurring at the midelevations (Rosenzweig, 1995) with relatively less at the lower and higher elevations. Conversely, Patterson et al. (1998) found a decreasing trend in bat and bird richness as elevation increased. In 2000, NASA and the United States National Imagery and Mapping Agency (NIMA) launched the Shuttle Radar Topography Mission (SRTM) which has made available $90-\mathrm{m}$ spatial resolution data, for $80 \%$ of the Earth surface, between $\pm 60^{\circ}$ latitude (Farr and Kobrick, 2000). Utilising this highly consistent and freely available dataset, Iwanicka et al. (2008) undertook a regional analysis to investigate, at the $1 \mathrm{~km}$ resolution, which of a number of terrain attributes, such as mean, standard deviation, and normalised mean, produced the most significantly separable discrimination across the country. The research demonstrated that the zscore of elevation (the scaled elevation 90-m elevation within each $1 \mathrm{~km}$ cell) provided the most significant differentiation of topography across the range of environments across Canada and, as a result, forms the first indicator in this regionalization. 


\subsection{Land cover}

While climate and productivity have been linked to broad global patterns of biodiversity (Willig et al., 2003; Hawkins et al., 2003), finer scale spatial patterns such as land use and land cover, forest structural stage, and their associated spatial patterns, are increasingly being investigated as potential predictors of species diversity and abundance at regional and local scales (Fahrig, 2003). Land cover maps, in particular, depicting individual or assemblages of land cover types or species are critical to biodiversity assessments as they represent a "first-order" analysis of species occurrence (Turner et al., 2003). Additionally, land cover data may prove useful as a predictive variable when assessing habitat diversity of species not directly imaged by the remote sensor system. Kerr et al. (2001), for example, applied land cover from by satellite data along with environmental measurements of potential and actual evapotranspiration, and vegetation production, to predict butterfly species richness across Canada. Study findings revealed that over $90 \%$ of butterfly species richness could be explained by the number of land cover types.

Information on current land cover is available at the $1 \mathrm{~km}$ scale from the University of Maryland (UMD) land cover classification (Hansen et al., 2000). The dataset is derived from Moderate Resolution Imaging Spectroradiometer (MODIS) satellite data and was developed using a classification tree approach based on the individual spectral bands as well as spectral transformations to enhance vegetation greenness. The application of the tree classier utilizes an hierarchy of vegetation types similar to that discussed by Running et al. (1994), however the relationships between the remote sensing data and vegetation type are empirically derived (Hansen et al., 2000). The classification defines 14 land cover classes, including evergreen needleleaf, evergreen broadleaf, deciduous needleleaf and deciduous broadleaf forest, and a fifth mixed forest class. The remaining classes include 2 classes each for shrub and woodland complexes grassland, cropland, bare ground, urban, and water. 


\subsection{Vegetation productivity}

A direct correlation between landscape productivity and species richness is expected as areas of high production have more resources to partition among competing species; thereby, supporting a greater number of species and larger populations than areas with lower production (Walker et al., 1992). Using remotely sensed data, vegetation production can be assessed through relationships with standing biomass, such leaf area index (LAI) or canopy light absorption. A key metric of vegetation production from satellite imagery is the prediction of the fraction of photosynthetically active radiation (fPAR) intercepted by vegetation, which is analogous to greenness cover (Knyazikhin et al., 1998) and ranging from zero (on barren land) to one (for dense cover). In theory, the higher the average fPAR level observed over the course of a seasonal plant growing cycle, the more dense the green leaf cover, the higher the productivity, and the less disturbed the vegetation cover. Potter et al. (2003) demonstrated that 10 years of greenness observations (fPAR), observed by daily satellite observations, provided a successful means to monitor large-area ecosystem behaviour.

In order to condense daily or weekly time series of fPAR we implement a Dynamic Habitat Index (DHI) proposed by Mackey et al. (2004) and Berry et al. (2007) and applied to Canada by Coops et al. (2008c). The index utilises a time series of satellite observations of greenness to derive three indicators of the underlying vegetation dynamics; the total annual production, the minimum level of perennial cover, and the degree of vegetation seasonality. To derive the index we utilized data from the MODIS sensors, launched in 2000 and 2002 on the Terra and Aqua platforms which provide two-daily coverage of the globe at $1 \mathrm{~km}$ spatial resolution in 36 spectral bands (Heinsch et al., 2006). MODIS data provides not only improvements in spatial and spectral resolution compared with NOAA's Advanced Very High Resolution Radiometer (AVHRR) sensors, but also include state-of-the-art engineering to provide improved geo-referencing, atmospheric correction, and cloud-screening capabilities (Justice et al., 2002). NASA provides a suite of data products on a routine basis, including calibrated fPAR which is derived from seven spectral bands, taking into account sun angle, background reflectance, and view angle influences (Yang et al., 2006). To minimize the 
influence of cloud and snow cover, atmospheric variation, and other confounding environmental conditions, the maximum daily fPAR is selected for each 8-day period and these 8-day composites combined into monthly maximum fPAR products and mapped at a spatial resolution of $1 \mathrm{~km}$. Global fPAR monthly images from 2000 to 2005 were accessed from the Boston University Climate and Vegetation research group website (http://cliveg.bu.edu).

From these data we computed the three $\mathrm{DHI}$ components: Annual primary production which can be expressed as integrated greenness over the growing season, or for the entire year. Our annual estimate of greenness was derived by summing monthly fPAR observations for each year, and then averaging annual productivity for the period 20002005. The annual remotely-sensed index of landscape greenness has a strong theoretical base (Goward et al., 1985), as well as empirical justification for forests (Coops et al., 1999), grasslands (Wang et al., 2004), and crops (Groten, 1993). Annual minimum cover relates the potential of a given landscape to support permanent resident species throughout the year (Schwartz et al., 2006). Locations bereft of significant snow cover accumulations following summer often maintain greenness into winter, and fPAR remains above 0 . In areas where snow covers the vegetation, fPAR approaches 0 . The higher the value of annual minimum cover the more permanent vegetated cover remains throughout the year. Seasonal variation in greenness, expressed by FPAR, is an integrated measure of climate, topography, and land use. For example, forests and grasslands at northern latitudes display a much shorter growing season and higher seasonality than those in more southern areas. Many researchers have used greenness indices, such as fPAR, to estimate the length of the growing season and to compare seasonal variation among sites and from one year to another (Reed et al., 1994). To assess variation in the fPAR throughout the year, we computed the standard deviation of monthly values for each cell, and then divided that value by the mean annual fPAR to attain the coefficient of variation (CV). High CV values signify seasonal extremes in climatic conditions or limited periods with agricultural production. Sites with low CV typically represent irrigated year around pasture, barren land, or evergreen forests. The 
three annual DHI composite were then averaged over the 5 years to provide a long term average $\mathrm{DHI}$ for this study.

A summary of the three sets of remotely sensed indicators used in the study are provided in Table 1.

Table 1: A summary of the characteristics of the three suites of indicators derived from remote sensing technologies, utilise by the regionalization.

\begin{tabular}{|c|c|c|c|}
\hline & Topography & Production & Land cover \\
\hline Image spatial & $90 \mathrm{~m}<60^{\circ} \mathrm{N}$ & $1000 \mathrm{~m}$ & $1000 \mathrm{~m}$ \\
\hline resolution / grain & $1000 \mathrm{~m}>60^{\circ} \mathrm{N}$ & & \\
\hline Image extent & Canada Wide & All vegetated areas & Global \\
\hline $\begin{array}{l}\text { Type of remotely } \\
\text { sensed data }\end{array}$ & RADAR & MODIS fPAR & AVHRR Land cover \\
\hline Platform & Shuttle & Terra / Aqua & AVHRR / MODIS \\
\hline Temporal Capacity & Single & Monthly / Annual & Once \\
\hline Ownership / cost & Free & Free & Free \\
\hline Size of Dataset & $250 \mathrm{MB}$ & $100 \mathrm{MB}$ & $300 \mathrm{MB}$ \\
\hline $\begin{array}{l}\text { Processing } \\
\text { strategy }\end{array}$ & $\begin{array}{l}\text { Coefficient of Variation } \\
\text { (COV) }\end{array}$ & $\begin{array}{l}\text { Dynamic Habitat Index } \\
\text { (DHI) }\end{array}$ & $\begin{array}{l}\text { Image classification, Pattern } \\
\text { indices }\end{array}$ \\
\hline $\begin{array}{l}\text { Processing } \\
\text { strategy references }\end{array}$ & $\begin{array}{l}\text { Wilson and Gallant } \\
(2000)\end{array}$ & $\begin{array}{l}\text { Mackey et al. (2004), } \\
\text { Coops et al. (2008c) }\end{array}$ & Hansen et al. (2000) \\
\hline
\end{tabular}

\subsection{Ecological Stratification of Canada: Ecozones}

To obtain descriptions of the various biomes across Canada, we utilized the National Ecological Framework of Environment Canada (Rowe and Sheard, 1981). Stratification of biomes are based on an underlying expert derived classification system where each region is viewed as a discrete ecological system, with interactions between geology, landform, soil, vegetation, climate, wildlife, water, and human factors (see Bailey et al. (1985) for a review of ecological regionalization in Canada). Ultimately, seven levels of generalization are available with 15 terrestrial "ecozones" forming the broadest of these spatial generalizations (Rowe and Sheard, 1981; Wiken, 1986; Ironside, 1991). The commonly used ecozone level of stratification for national investigations (Table 2), which is also shown in Figure 1(d), provides a basis for comparison of the clusters developed in this paper. 
Table 2: A description of the 15 terrestrial "ecozones" which form the broadest of the Environment Canada classification.

\begin{tabular}{|c|c|c|c|c|}
\hline Ecozone & Climate & Vegetation / productivity & $\begin{array}{l}\text { Land Area }\left(\mathrm{km}^{2}\right) \\
\text { \%of Total Area }\end{array}$ & $\begin{array}{c}\text { Canadian } \\
\text { population (\%) }\end{array}$ \\
\hline $\begin{array}{l}\text { Arctic } \\
\text { Cordillera }\end{array}$ & $\begin{array}{l}\text { Extremely cold, dry; } \\
\text { continuous permafrost }\end{array}$ & $\begin{array}{l}\text { Mainly un-vegetated; some } \\
\text { shrub-herb tundra }\end{array}$ & $\begin{array}{c}230873 \\
2 \%\end{array}$ & $<0.01$ \\
\hline $\begin{array}{l}\text { Northern } \\
\text { Arctic }\end{array}$ & $\begin{array}{l}\text { Very cold, dry; continuous } \\
\text { permafrost }\end{array}$ & Herb-lichen tundra & $\begin{array}{c}1361433 \\
14 \%\end{array}$ & 0 \\
\hline $\begin{array}{l}\text { Southern } \\
\text { Arctic }\end{array}$ & $\begin{array}{l}\text { Cold, dry; continuous } \\
\text { permafrost }\end{array}$ & Shrub-herb tundra & $\begin{array}{c}773041 \\
8 \%\end{array}$ & 0 \\
\hline Taiga Plains & $\begin{array}{l}\text { Cold, semiarid to moist; } \\
\text { discontinuous permafrost }\end{array}$ & Open to closed mixed forest & $\begin{array}{c}580139 \\
6 \%\end{array}$ & 0 \\
\hline Taiga Shield & $\begin{array}{l}\text { Cold, moist to semiarid; } \\
\text { discontinuous permafrost }\end{array}$ & $\begin{array}{l}\text { Open evergreen and } \\
\text { deciduous, lichen, shrub, } \\
\text { tundra }\end{array}$ & $\begin{array}{c}1253887 \\
13 \%\end{array}$ & 0 \\
\hline $\begin{array}{l}\text { Hudson } \\
\text { Plains }\end{array}$ & $\begin{array}{l}\text { Cold to mild, semiarid; } \\
\text { discontinuous permafrost }\end{array}$ & $\begin{array}{l}\text { Wetland; some herb, lichen } \\
\text { tundra, evergreen forest }\end{array}$ & $\begin{array}{c}353364 \\
4 \%\end{array}$ & 0 \\
\hline Boreal Shield & Cold, moist & $\begin{array}{l}\text { Evergreen forest, mixed } \\
\text { evergreen, deciduous forest }\end{array}$ & $\begin{array}{c}1782252 \\
18 \%\end{array}$ & 10 \\
\hline $\begin{array}{l}\text { Atlantic } \\
\text { Maritime }\end{array}$ & Cool, wet & $\begin{array}{l}\text { Mixed deciduous, evergreen } \\
\text { forest }\end{array}$ & $\begin{array}{c}183978 \\
2 \%\end{array}$ & 9 \\
\hline $\begin{array}{l}\text { Mixedwood } \\
\text { Plains }\end{array}$ & Cool to mild, moist & $\begin{array}{l}\text { Mixed deciduous, evergreen } \\
\text { forest }\end{array}$ & $\begin{array}{c}138421 \\
1 \%\end{array}$ & 51 \\
\hline Boreal Plains & Cold, moist & $\begin{array}{l}\text { Mixed evergreen, deciduous } \\
\text { forest }\end{array}$ & $\begin{array}{c}679969 \\
7 \%\end{array}$ & 3 \\
\hline Prairies & Cold, semiarid & $\begin{array}{l}\text { Grass; scattered deciduous } \\
\text { forest }\end{array}$ & $\begin{array}{c}469681 \\
5 \%\end{array}$ & 14 \\
\hline $\begin{array}{l}\text { Taiga } \\
\text { Cordillera }\end{array}$ & $\begin{array}{l}\text { Cold, semiarid; } \\
\text { discontinuous permafrost }\end{array}$ & Shrub, herb, moss, tundra & $\begin{array}{c}264480 \\
3 \%\end{array}$ & $<0.01$ \\
\hline $\begin{array}{l}\text { Boreal } \\
\text { Cordillera }\end{array}$ & Moderately cold, moist & $\begin{array}{l}\text { Largely evergreen forest; } \\
\text { some tundra, open woodland }\end{array}$ & $\begin{array}{c}459680 \\
5 \%\end{array}$ & 0 \\
\hline $\begin{array}{l}\text { Pacific } \\
\text { Maritime }\end{array}$ & $\begin{array}{l}\text { Mild, temperate, very wet to } \\
\text { cold alpine }\end{array}$ & Coastal evergreen forest & $\begin{array}{c}205175 \\
2 \%\end{array}$ & 9 \\
\hline $\begin{array}{l}\text { Montane } \\
\text { Cordillera }\end{array}$ & Moderately cold, moist to arid & $\begin{array}{l}\text { Evergreen forest, alpine } \\
\text { tundra, interior grassland }\end{array}$ & $\begin{array}{c}479057 \\
5 \%\end{array}$ & 3 \\
\hline
\end{tabular}

\subsection{Analysis}

Once the three sets of remotely sensed data were assembled, we classified the approximately 18 million $1 \mathrm{~km}$ grid cells using a two-stage multivariate classification applying the two-step algorithm available in SPSS (Zhang et al., 1996). The algorithm is particularly useful in the clustering of environmental data as it allows for both continuous and categorical data. The algorithm undertakes an initial first pass to develop a cluster tree which essentially efficiently clusters the large number of cells into a smaller number of clusters (Zhang et al., 1996). Once the initial pre-clustering has been undertaken, the clusters are then grouped using an agglomerative hierarchical clustering method. In both the first and second passes through the data a distance measure is created. In our 
approach, the log-likelihood distance measure was utilised as it can accommodate both continuous and categorical variables and provides a probability based distance which is related to the decrease in log-likelihood as one cluster is combined with another (Zhang et al., 1996). Our approach was to develop a relatively large number of initial classes (100) using the two-step process and then apply hierarchical clustering approach to derive two finer levels of organisation. The first, a 40 level classification was developed allowing identification of groups of pixels which were the most dissimilar to the majority indicative of unique environments across Canada. From this, a second level of clustering was derived at the 14 class level, desired to emulate the level of organizational detail of the current ecozone stratification commonly used in Canada.

Following the clustering, the derived clustering levels were imported into a geographic information system for display and analysis. Although two clustering levels (40 and 14 clusters) were derived for national level analysis in this paper, these clustering levels are user defined and additional analysis could be undertaken allowing the derivation of a larger number of clusters, and subsequently more detail, which may be more suited for regional level analysis.

\section{RESULTS}

The results of the clustering analysis from the initial 100 pre-clusters, to the 40 , and 14 cluster levels is diagrammatically presented in the dendogram in Figure 2. At the $15 \%$ scaled distance 40 clusters are formed, with the 14 cluster level reached at the $25 \%$ distance level. Once each cluster was formed at the 40 level, the log-likelihood distance measure was computed between each of the clusters, and the clusters with the 10 largest distances to any neighbouring clusters were extracted. These clusters are shown in Figure 3. In addition, Table 3 shows the percent of the total area of the country captured by each of these 10 most unique clusters, as well as the relative rank of the minimum cover, overall productivity, seasonally and terrain for each of the clusters. 


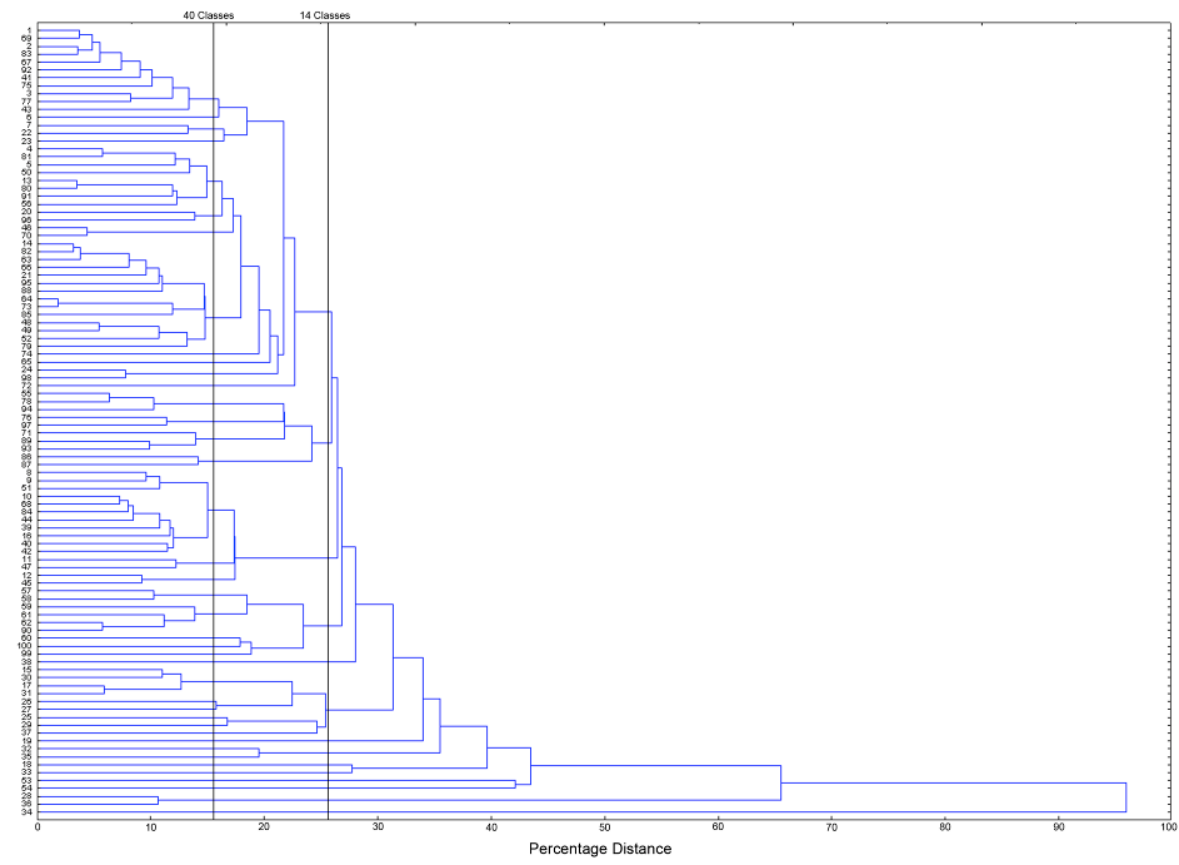

Figure 2: The results of the clustering analysis from the initial 100 pre-clusters, to the 40 , and 14 cluster levels is diagrammatically shown as a dendogram.

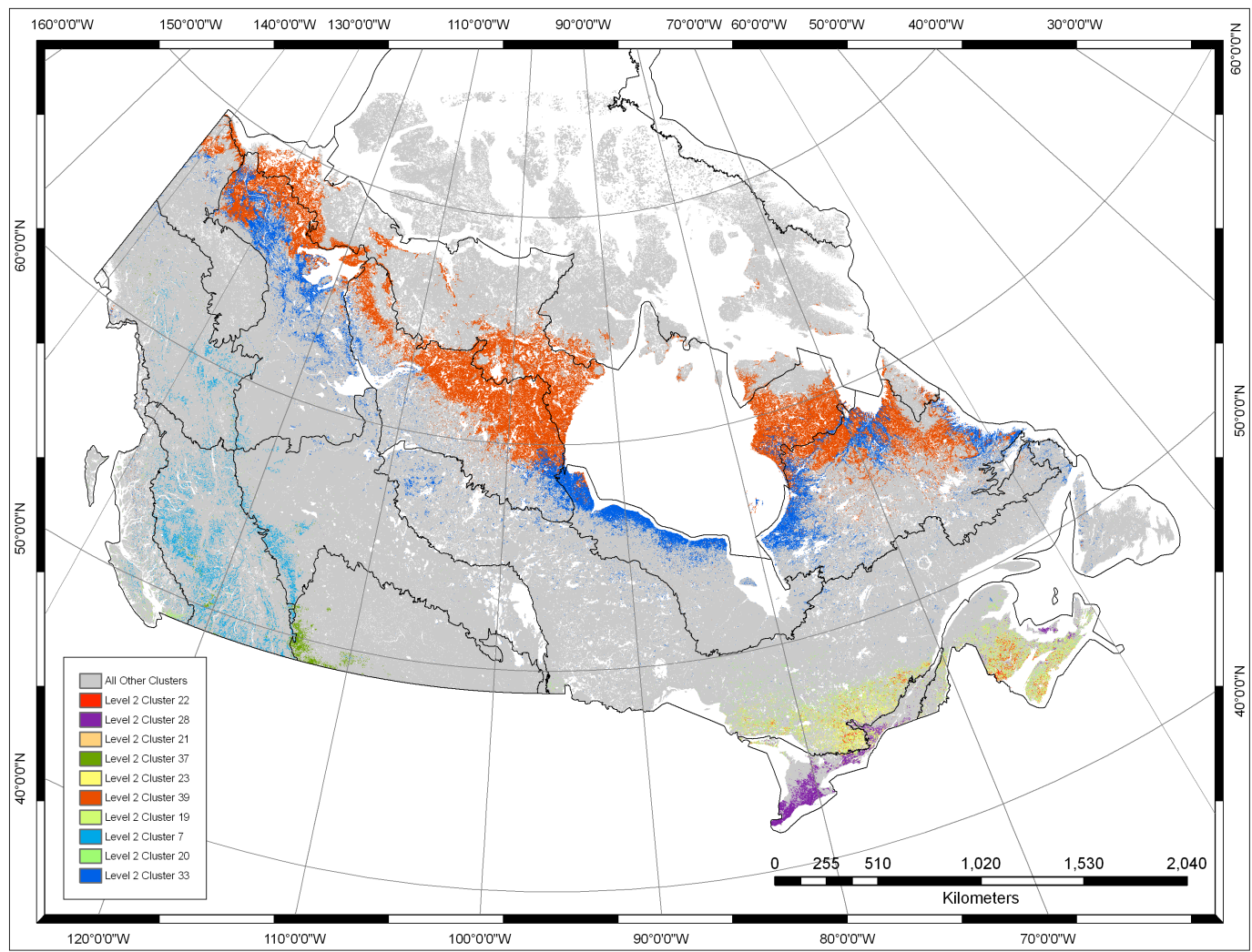

Figure 3: Map of the 10 most unique clusters across Canada defined as the 10 clusters with the largest distances to any neighbouring clusters. 
Table 3: The 10 most unique clusters as defined from the regionalization and the relative ranking of the remotely sensed derived indicators.

\begin{tabular}{rrrrrrrr}
\hline Cluster & ID & $\begin{array}{c}\text { \% of } \\
\text { Canada }\end{array}$ & $\begin{array}{c}\text { Minimum } \\
\text { Cover }\end{array}$ & Seasonality & Productivity & Terrain & General Location \\
\hline 1 & 22 & $0.15 \%$ & 1 & 40 & 1 & 39 & Central On / SW QB \\
2 & 28 & $0.40 \%$ & 15 & 30 & 9 & 36 & Southern Ontario \\
3 & 21 & $0.52 \%$ & 4 & 37 & 3 & 29 & Central On / SW QB \\
4 & 37 & $0.22 \%$ & 25 & 22 & 18 & 11 & SW Alberta Foothills \\
5 & 23 & $0.24 \%$ & 8 & 33 & 6 & 31 & Central On / SW QB \\
6 & 39 & $8.38 \%$ & 33 & 38 & 27 & Southern Arctic \\
7 & 19 & $0.35 \%$ & 3 & 39 & 2 & 34 & Central On / SW QB \\
8 & 7 & $1.21 \%$ & 13 & 35 & 5 & 26 & Central On / SW QB \\
9 & 20 & $0.66 \%$ & 6 & 11 & 33 & 37 & Northern Boreal \\
10 & 33 & $3.73 \%$ & 28 & & & &
\end{tabular}

As expected, the 10 unique clusters rank most commonly either high or low when compared to the remaining 30 clusters, in part explaining why these 10 clusters were separated from the majority. The results confirm that the unique clusters exist in a number of locations over Canada (Figure 3). The most unique cluster (red, cluster 22) occurs in the Mixedwood Plain ecozone, in Southern Ontario. For this cluster, the indicator variables are high productivity, with low seasonality, and high minimum cover (indicative of little to no persistent snow accumulation). The area is also composed of relatively flat landscapes. The second most unique cluster (purple, cluster 28) occurs in southern Ontario around the Lake Erie lowland and south of the Frontenac Axis. This cluster is moderately seasonal, with snow cover occurring the winter, and is moderately productive. The area is of relatively low topographic relief compared to the surrounding areas and dominated by the MODIS cropland land cover class. The third suite of unique clusters is found in the southern portion of Ontario and Western Quebec, with the clusters occurring heavily populated areas, with a complex mosaic of land cover types and land uses present, totalling around $2 \%$ of the country, all exhibiting low seasonality, high levels to minimum cover, and high production. The major difference driving their "uniqueness" is the different MODIS land cover including mixed forest and deciduous MODIS classes. The remaining unique clusters across Canada include the south western Alberta foothills, regions of the southern Arctic and the northern Boreal, in particular the areas south of Hudson Bay and Labrador. 
Merging the clusters to the 14 cluster level (Figure 4a-d), commensurate with the existing ecozone classification undertaken by Environment Canada, allows the new clusters, based on current vegetation condition, topography and land cover to be compared to each other across the country as well as to the existing ecoregion classification (Table 4). The first cluster (Figure 4b) encompasses much of the evergreen broadleaf boreal forest in Canada (approximately $12 \%$ of the country), which is ranked moderately with respect to productivity, seasonality and minimum levels of cover. The terrain in the cluster is ranked $9^{\text {th }}$ out of $14^{\text {th }}$ indicating the cluster is generally more flat compared to the other clusters. The second cluster is situated west in the Rocky Mountains and is similar to the first cluster with respect to its vegetation characteristics however is much higher in elevation. Clusters 3 and 4 cover the highly productivity, low seasonality, evergreen needleleaf forests of the west coast of Canada and Vancouver Island with Cluster 4 containing slightly higher productivity, evergreen, forests with little seasonality and snow cover. Clusters 5 (Figure 4c) represents the most productive forest in Canada and consists of the needleleaf forests in eastern Canada in Southern Ontario, Quebec and Nova Scotia. Clusters 6 and 7 cover the moderately productive and seasonal mixed deciduous and needleleaf forest in Eastern Canada which also occurs in scattered patches throughout the Boreal forest. Cluster 8 encompasses the dominant croplands of the Prairies with a higher rank of minimum cover indicating that the cluster experiences at least some snow cover throughout the year. It also is ranked $5^{\text {th }}$ with respect to productivity and $10^{\text {th }}$ with seasonality indicating that the vegetation at some point throughout the year would reach a dormant state, as may be expected in agricultural crop rotation. Cluster 9 (Figure 4d) encompasses the barren and sparse vegetation of the Arctic typified by the lowest productivity found in Canada, the lowest amount of continual green vegetation, and high seasonality vegetation over very flat terrain. Cluster 10 highlights more natural vegetation and grasslands within some portions of the Prairies and in northern Canada. These cells are similar in vegetation characteristics to the cropland cluster (8) except they occur at higher elevation, are less productive, and experience higher degrees of snow cover throughout the year. Clusters 11 covers the woody savanna (Taiga) landscapes in the transition zone between the southern Arctic and northern Boreal forests, and cluster 12 
covers the relatively unique landscape, highlighted previously, south of Hudson Bay typified by open shrub land with moderate productive, seasonality and terrain. Cluster 13 is characterised by shrub vegetation in the southern Arctic with low productivity, high seasonality. The final cluster (14) is typified by similar conditions, however at higher terrain in the western Yukon, adjacent to Alaska.
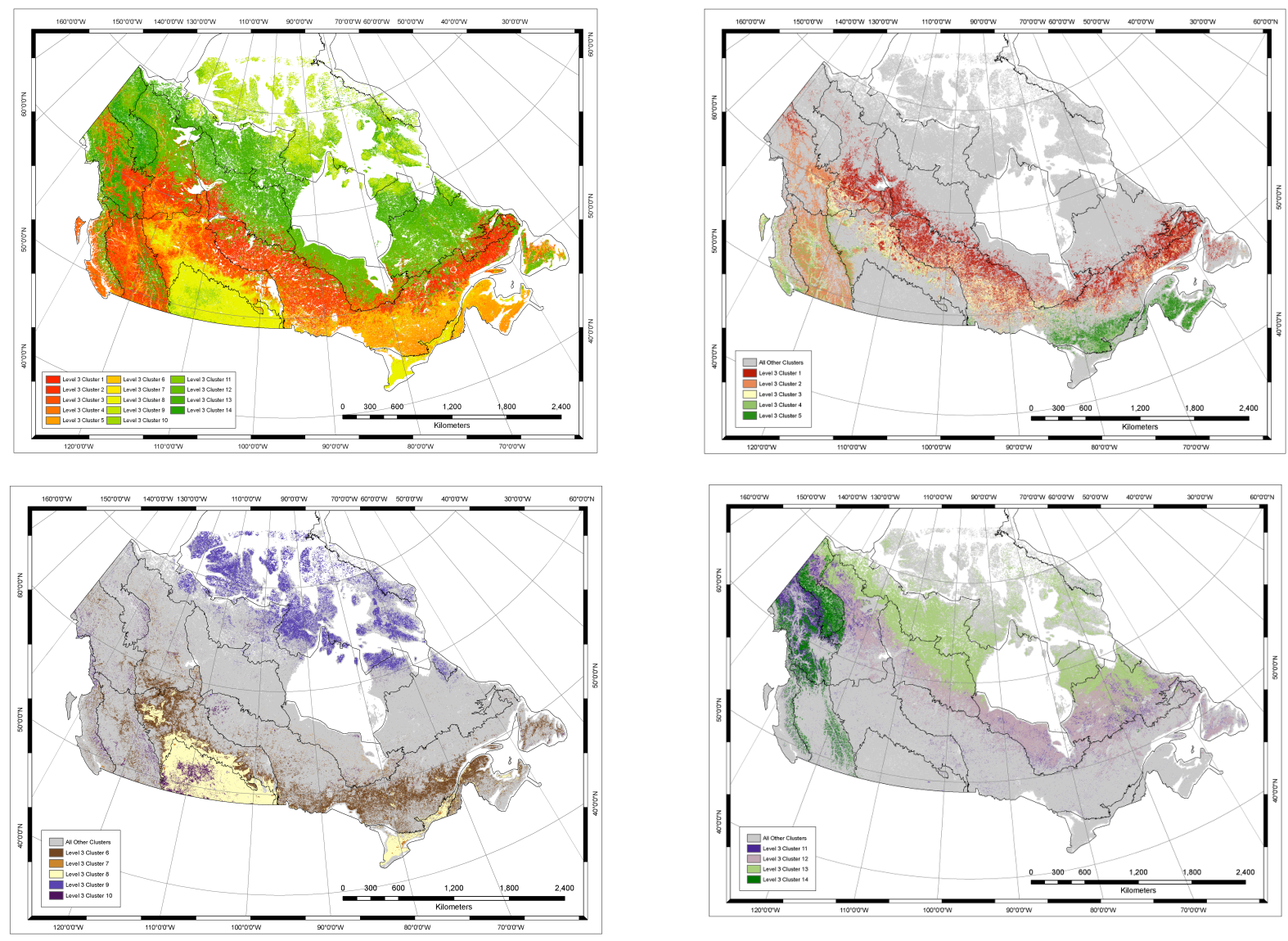

Figure 4 (a)-(d): Four maps of the 14 clusters derived from the regionalization; (a) All clusters, (b) Cluster 1 5, (c) Cluster 5 - 10, and (d) Cluster $11-14$. 
Table 4: Description of the 14 derived cluster and the relative rank of the remotely sensed indicators.

\begin{tabular}{|c|c|c|c|c|c|c|c|}
\hline Cluster & $\begin{array}{c}\% \text { Total } \\
\text { Area }\end{array}$ & $\begin{array}{c}\text { Minimum } \\
\text { Cover }\end{array}$ & Productivity & Seasonality & Terrain & Dominant Land Cover & $\%$ \\
\hline 1 & 11.70 & 7 & 9 & 7 & 9 & Evergreen Needleleaf & 100 \\
\hline 2 & 4.80 & 6 & 6 & 9 & 2 & Evergreen Needleleaf & 100 \\
\hline 3 & 7.50 & 3 & 3 & 12 & 8 & Evergreen Needleleaf & 100 \\
\hline 4 & 2.80 & 2 & 2 & 13 & 4 & Evergreen Needleleaf & 78 \\
\hline 5 & 2.70 & 1 & 1 & 14 & 14 & Evergreen Needleleaf & 100 \\
\hline 6 & 10.30 & 4 & 4 & 11 & 7 & Mixed Forest & 100 \\
\hline 7 & 0.80 & 5 & 7 & 8 & 11 & Deciduous Needleleaf & 43 \\
\hline 8 & 8.00 & 10 & 5 & 10 & 6 & Cropland & 100 \\
\hline 9 & 8.60 & 14 & 14 & 1 & 13 & Barren/Sparse Vegetation & 100 \\
\hline 10 & 2.40 & 11 & 8 & 6 & 3 & Grasslands & 86 \\
\hline 11 & 4.80 & 9 & 10 & 5 & 5 & Woody Savanna & 100 \\
\hline 12 & 14.50 & 8 & 11 & 4 & 10 & Open Shrub land & 100 \\
\hline 13 & 16.60 & 12 & 13 & 2 & 12 & Open Shrub land & 100 \\
\hline 14 & 4.40 & 13 & 12 & 3 & 1 & Open Shrub land & 100 \\
\hline
\end{tabular}

Table 5: Relationship between the derived clusters and the existing 15 class Environment Canada ecozone classification.

\begin{tabular}{|c|c|c|c|c|c|c|c|c|c|c|c|c|c|c|}
\hline Ecozone & 1 & 2 & 3 & 4 & 5 & 6 & 7 & 8 & 9 & 10 & 11 & 12 & 13 & 14 \\
\hline $\begin{array}{l}\text { Northern } \\
\text { Arctic }\end{array}$ & & & & & & & & & $\begin{array}{l}68 . \\
58\end{array}$ & $\begin{array}{c}0.7 \\
4\end{array}$ & $\begin{array}{c}0.0 \\
1\end{array}$ & & $\begin{array}{l}30 . \\
58\end{array}$ & $\begin{array}{c}0.0 \\
8\end{array}$ \\
\hline Arctic & 0.0 & 0.0 & & & & 0.0 & & & 52. & 1.2 & 0.9 & 1.3 & 38. & 5.6 \\
\hline Cordillera & 3 & 3 & & & & 1 & & & 25 & 2 & 1 & 8 & 53 & 6 \\
\hline Southern & & & & & & & & & 17. & 1.5 & 0.0 & 0.7 & 80. & \\
\hline Arctic & & & & & & & & & 33 & 7 & 2 & 6 & 32 & \\
\hline Taiga & 0.8 & 1.5 & & 0.0 & & 0.3 & 0.1 & & 0.8 & 4.6 & 16. & 11. & 10. & 52. \\
\hline \multirow[t]{2}{*}{ Cordillera } & 0 & 2 & & 6 & & 4 & 6 & & 0 & 8 & 76 & 80 & 30 & 77 \\
\hline & 20. & 2.7 & 8.7 & 0.8 & 0.0 & 8.1 & 1.4 & 0.0 & 0.0 & 1.7 & 9.2 & 27. & 16. & 2.3 \\
\hline Taiga Plain & 48 & 2 & 8 & 5 & 3 & 9 & 0 & 1 & 7 & 8 & 1 & 43 & 67 & 8 \\
\hline Taiga & 13. & 0.0 & 0.4 & & & 0.2 & 0.2 & & 0.4 & 0.4 & 5.0 & 42. & 36. & 0.0 \\
\hline Shield & 70 & 9 & 4 & & & 5 & 0 & & 6 & 7 & 6 & 98 & 34 & 1 \\
\hline Boreal & 3.5 & 25. & 3.6 & 0.6 & & 4.6 & 0.3 & 0.0 & 0.4 & 3.2 & 26. & 2.2 & 0.2 & 28 \\
\hline \multirow[t]{2}{*}{ Cordillera } & 7 & 59 & 6 & 4 & & 6 & 7 & 1 & 3 & 1 & 86 & 3 & 9 & 47 \\
\hline & 11. & 3.9 & 20. & 6.2 & 0.6 & 30. & 1.3 & 20. & 0.0 & 1.1 & 1.8 & 1.9 & 0.0 & 0.0 \\
\hline Boreal Plain & 00 & 7 & 57 & 3 & 6 & 60 & 1 & 65 & 1 & 9 & 0 & 6 & 2 & 3 \\
\hline Pacific & 4.6 & 11. & 19. & 18. & 3.0 & 11. & 0.5 & 0.0 & 1.7 & 5.4 & 6.1 & 2.8 & 2.5 & 12. \\
\hline Maritime & 5 & 64 & 16 & 28 & 8 & 63 & 5 & 5 & 4 & 1 & 5 & 5 & 6 & 26 \\
\hline Boreal & 29. & 0.4 & 17. & 2.6 & 7.0 & 23. & 1.1 & 0.8 & 0.0 & 1.4 & 2.9 & 12. & 0.1 & 0.0 \\
\hline Shield & 94 & 9 & 75 & 4 & 1 & 06 & 3 & 6 & 4 & 0 & 6 & 51 & 9 & 3 \\
\hline Hudson & 15. & & 5.0 & 0.2 & 0.0 & 3.4 & 2.8 & & 0.0 & 1.6 & 6.7 & 63. & 1.6 & \\
\hline Plain & 02 & & 6 & 3 & 2 & 9 & 4 & & 1 & 6 & 7 & 24 & 6 & \\
\hline Montane & 0.6 & 41. & 8.2 & 15. & 0.3 & 9.7 & 0.3 & 0.4 & 0.1 & 4.7 & 3.8 & 0.7 & 0.0 & 13 \\
\hline \multirow[t]{2}{*}{ Cordillea } & 2 & 61 & 1 & 59 & 7 & 2 & 0 & 2 & 2 & 7 & 0 & 5 & 9 & 60 \\
\hline & 0.0 & 0.0 & & 0.0 & & 0.2 & 0.3 & 85. & 0.0 & 13. & 0.1 & 0.2 & & 0.1 \\
\hline Prairie & 1 & 1 & & 6 & & 8 & 1 & 17 & 1 & 71 & 6 & 0 & & 0 \\
\hline Atlantic & 0.5 & 0.0 & 1.2 & 7.9 & 42. & 36. & 0.6 & 8.8 & & 0.6 & 0.5 & 0.8 & & \\
\hline Maritime & 3 & 3 & 4 & 9 & 51 & 29 & 2 & 6 & & 0 & 3 & 0 & & \\
\hline MixedWood & 0.1 & & 0.3 & 6.3 & 4.8 & 8.0 & 4.4 & 73. & 0.0 & 0.8 & 0.5 & 0.9 & & \\
\hline Plain & 4 & & 2 & 5 & 3 & 2 & 1 & 55 & 1 & 4 & 5 & 7 & & \\
\hline
\end{tabular}


Comparing the derived clusters to the existing ecoregions, provides a comparison of how well the remotely derived indicators used in the regionalization compare to the existing, more traditionally developed, approaches. Table 5 provides the breakdown of the clusters, by ecozone occupancy, and demonstrates the Northern Arctic, Arctic Cordillera and Southern Arctic are essentially covered by clusters 9 and 13. However, cluster 13 also covers a wide variety of vegetation conditions with overlap in the Taiga ecoregions. The Taiga Cordillera area is represented principally by Cluster 14 , but also Clusters $11-13$ covering the north regions of the country. Cluster 12 covers the Taiga shield and the Taiga plain and the vegetation around the south of Hudson Bay. Cluster 10 is a broad assemblage of classes without a single dominant existing ecoregion type, except for $10 \%$ of the current Prairie ecozone. Cluster 8 has almost direct correspondence with the existing Prairie ecoregion and the agricultural component of the mixed wood plains ecoregion, principally driven by the current land cover indicator. Similarly cluster 5 is principally comprised of the Atlantic Maritime ecoregion. Clusters 3 and 4 comprise the majority of the Pacific Maritime and the Montane Cordillera ecoregions, with Clusters 1 and 2 covering a mixture of the Boreal Cordillera, Boreal Shield, and Hudson Plain ecoregions.

\section{DISCUSSION}

One of the key benefits of deriving ecoregions quantitatively using key indicators, such as those derived from remote sensing observations and encapsulating information on vegetated land cover productivity, seasonality and terrain, is the capacity to establish, and quantify how well, particular networks of sites, or plot locations, represent the overall environment. In the case of biodiversity monitoring it is critically important to ensure that field based monitoring programs either through sites, national parks programs, or focused conservation areas, are well placed, and optimised to capture as much information as possible, given limited resources. To do this, the current geographic positions of these ongoing biodiversity efforts over the country can be compared to the derived clusters, and the log-likelihood distance measures between these locations and all of the clusters derived. Clusters which have the largest distances from the current areas of focus will essentially be poorly represented by the existing 
network. Conversely, this type of analysis can aid in the establishment of new biodiversity focused environmental programs by providing an initial stratification of where additional work should be focused to ensure a more even representation of the biota.

Similarly the quantitative development of clusters using this type of regionalization ensures that each defined cluster or ecoregion can be regarded, at the output scale of resolution, as homogenous ensuring that the resultant management of that unit is more appropriate, robust and consistent than applying a more random approach to biodiversity management and conservation (Leathwick et al., 2003). This is particularly apt for the more unique environments, which include in Canada, wetlands and mixed wood environments which have a variety of broadleaf and needleleaf species.

While the quantitative approach presented in this paper is an attempt to provide options where appropriate aside from more subjective methods of ecoregion delineation, the choice of the initial input indicators, and their respective weightings, as well as the selection of the output number of clusters remains subjective. We believe the initial selection of the indicators used in the study is well justified by previous reviews describing the current state of the art approaches to represent biodiversity patterns of the landscape with demonstrated success in applying these indicators both in Canada and abroad (Coops et al, 2008a; Coops et al., 2008b; Berry et al., 2007). The approach however is not limited to this selection of input indicators and additional layers could be added. One potential addition could be remotely sensed layers of disturbance. Disturbance often plays an essential role in regulating competitive exclusion and enhancing the spatial heterogeneity of vegetation communities, both of which may enhance diversity (Spies and Turner, 1999; Duro et al., 2007). Further, with natural fire regimes largely intact for much of Canada's boreal, the presence of change is an actual component of the ecosystem. Remote sensing technology has been shown to be successful at monitoring disturbance (Foody et al., 1996; Rignot et al., 1997) particularly disturbance events which result in stand replacement such as fire, clear cut harvesting, and wind throw. If this type of information were added however, the clusters would 
reflect a combination of both the current vegetation and terrain conditions as well as the underlying disturbance regimes. The manner in which disturbance is incorporated into the ecosystem regionalization will require methods different from those proposed here, with object-based classification methods likely required.

\section{ACKNOWLEDGEMENTS}

This research was undertaken as part of the "BioSpace: Biodiversity monitoring with Earth Observation data" project jointly funded by the Canadian Space Agency (CSA) Government Related Initiatives Program (GRIP), Canadian Forest Service (CFS) Pacific Forestry Centre (PFC), and the University of British Columbia (UBC). 


\section{REFERENCES}

Austin, M.P., Nicholls, A.O., and Margules, C.R., 1990. Measurement of the realised qualitative niche: environmental niches of five Eucalyptus species. Ecological Monographs. 60, 161-177.

Bailey, R. G., Zoltai, S.C., and Wiken, E.B.,.1985. Ecological regionalization in Canada and the United States. Geoforum. 16, 265-275.

Belbin, L., 1993. Environmental representativeness: regional patterns and reserve selection. Biological Conservation. 66, 223-240.

Berry, S, Mackey,B., and Brown,T.,. 2007. Potential applications of remotely sensed vegetation greenness to habitat analysis and the conservation of dispersive fauna. Pacific Conservation Biology. 13, 112-127.

Busby, J.R., 1991. BIOCLIM - A bioclimate analysis and prediction system. In: C.R. Margules and M.P. Austin, (Editors), 1991. Nature Conservation: Cost Effective Biological Surveys and Data Analysis, CSIRO, Melbourne, Chapter 10.

Christensen, N.L., Bartuska, A.M., Brown, J.H., Carpenter, S., D'Antonio, C., Francis, R., Franklin, J.F., MacMahon, J.A., Noss, R.F., Parsons, D.J., Peterson, C.H., Turner, M.G. and Woodmansee, R.G., 1996. The report of the Ecological Society of America committee on the scientific basis for ecosystem management. Ecological Applications. 6, 665-691.

Coops, N. C., Bi,H., Barnett,P., and Ryan, P., 1999. Prediction of Mean and Current Volume Increments of a Eucalypt Forest using Historical Landsat MSS Data. Journal of Sustainable Forestry, 9, 149-168.

Coops, N.C., Waring,R.H., Wulder,M.A., Pidgeon, A.M., and Radeloff,V.C., 2008a. Bird diversity: A predictable function of satellite-derived estimates of seasonal variation in canopy light absorbance across the United States. Journal of Biogeography (in review).

Coops, N.C., Wulder, M.A., Iwanicka, D., 2008b. Assessing the relative importance of seasonal variation in production and land cover for satellite derived predictions of breeding bird distributions over Ontario, Canada. Remote Sensing of Environment (in review). 
Coops, N.C., Wulder, M.A., Duro, D.C., Han, T., and Berry, S., 2008c. The development of a Canadian Dynamic Habitat Index using multi-temporal satellite estimates of canopy light absorbance, Ecological Indicators. Vol. 8, pp. 754-766.

Duro, D.C., Coops, N.C., Wulder, M.A., and Han, T., 2007. Development of a large area biodiversity monitoring system driven by remote sensing. Progress in Physical Geography. 31, 1-26.

Fahrig, L., 2003. Effects of Habitat Fragmentation on Biodiversity. Annual Review of Ecology Evolution and Systematics. 34, 487-515.

Faith D. P., Nix,H. A., Margules,C. R., Hutchinson,M. F., Walker,P. A., West,J., Stein,J. L., Kesteven,J. L. Allison,A., and Natera, G, 2001. The BioRap biodiversity assessment and planning study for Papua New Guinea. Pacific Conservation Biology. 4,279-288.

Farr, T. G., and Kobrick, M., 2000. Shuttle radar topography mission produces a wealth of data. EOS. 81, 583-585.

Foody, G. M., Palubinskas,G., Lucas,R.M., Curran,P.J., and Honzak, M.,.1996. Identifying terrestrial carbon sinks: classification of successional stages in regenerating tropical forest from Landsat TM data. Remote Sensing of Environment. 55, 205-216.

Goward, S. N., Cruickshanks,G. D., and Hope, A. S.,.1985. Observed relation between thermal emission and reflected spectral radiance of a complex vegetated landscape. Remote Sensing of Environment. 18,137-146.

Groten, S. M. E., 1993. NDVI-crop monitoring and early yield assessment of Burkina Faso. International Journal of Remote Sensing. 14, 1495-1515.

Hansen, M., DeFries, R., Townshend,J. R. G., and Sohlberg, R., 2000. Global land cover classification at $1 \mathrm{~km}$ resolution using a decision tree classifier. International Journal of Remote Sensing. 21, 1331-1365.

Hargrove,W.W., and Hoffman,F.M., 1999. Using multivariate clustering to characterize ecoregion borders. Computing in Science and Engineering. 1, 18-25.

Hargrove, W.W., and Hoffman, F.M., 2005. Potential of multivariate quantitative methods for delineation and visualization of ecoregions. Environmental Management. 34, S39- S60. 
Hawkins, B.A., Field, R., Cornell, H.V., Currie, D.J., Guégan, J.-F., Kaufman, D.M., Kerr, J.T., Mittelbach, G.G., Oberdorff, T., O’Brien, E.M., Porter, E.E., and Turner, J.R.G., 2003. Energy, water and broad-scale geographic patterns of species richness. Ecology. 84, 3105-3117.

Heinsch, F.A., Zhao, M., and Running, S.W., 2006. Evaluation of remote sensing based terrestrial productivity from MODIS using regional tower eddy flux network observations. IEEE Transactions on Geoscience and Remote Sensing. 44, 19081925.

Hirzel, A.H., and Arlettaz, R., 2003. Modelling habitat suitability for complex species distributions by the environmental-distance geometric mean. Environmental Management. 32, 614-623.

Holdridge, L. R., 1947. Determination of world plant formations from simple climatic data. Science. 105, 367-368.

Host, G.E., Polzer, P.L., Mladenoff, D.J., White, M.A., and Crow, T.R., 1996. A quantitative approach to developing regional ecosystem classifications. Ecological Applications. 6, 608-618.

Ironside, G. R., 1991. Ecological land survey: Background and general approach. In H. A. Stelfox, G. R. Ironside and J. L. Kansas (Editors), Guidelines for the integration of wildlife and habitat evaluations with ecological land survey. Wildlife Habitat Canada and Canadian Wildlife Service Environment Canada Ottawa, Ontario. 107 pp.

Iwanicka, D., Coops, N.C., Wulder, M.A., 2008. Analysis of SRTM elevation residuals as analogue in biodiversity modeling. Canadian Journal of Remote Sensing (in prep).

Iverson, L.R., Prasad, A., Schwartz, M.W., 1999. Modeling potential future individual tree-species distributions in the eastern United States under a climate change scenario: a case study with Pinus virginiana. Ecological Modeling. 115, 77-93.

Justice, C. O., Townshend,J. R. G., Vermote,E. F., Masuoka,E., . Wolfe, R. E., Saleous,N., Roy,D. P., and Morisette, J. T., 2002. An overview of MODIS Land data processing and product status. Remote Sensing of Environment. 831, 3-15. 
Kerr, J.T., Southwood, T.R.E., and Cihlar, J., 2001. Remotely sensed habitat diversity predicts butterfly species richness and community similarity in Canada. Proceedings of the National Academy of Sciences of the United States of America. 98, 11365-11370.

Knyazikhin, Y., Kranigk, J., Myneni, R.B., Panfyorov, O., and Gravenhorst, G., 1998. Influence of small-scale structure on radiative transfer and photosynthesis in vegetation cover. Journal of Geophysical Research. 103, 6133-6144.

Leathwick, J.R., 2001. New Zealand's potential forest pattern as predicted from current species-environment relationships. New Zealand Journal of Botany. 39, 447464.

Leathwick, J.R., Overton, J.M., and McLeod, M., 2003. An environmental domain analysis of New Zealand, and its application to biodiversity conservation. Conservation Biology. 17, 1612-1623.

Lieth, H., 1975. Modeling the primary productivity of the world. In: H. Lieth and R. H. Whittaker (Editors), Primary productivity of the biosphere. Springer-Verlag, New York, New York, USA. 237-263 pp.

Lugo AE, Brown SL, Dodson R, Smith TS, Shugart HH. 1999. The Holdridge life zones of the conterminous United States in relation to ecosystem mapping. Journal of Biogeography 26. 1025-1038

Mackey, B. G., Nix,H. A., Hutchinson,M. F., MacMahon,J. P., and Fleming, P. M., 1988. Assessing representativeness of places for conservation, reservation and heritage listing. Environmental Management. 12, 501-514.

Mackey, B. G., Bryan,J., and Randall, L., 2004. Australia's Dynamic Habitat Template 2003. In: Proceedings MODIS Vegetation Workshop II University of Montana.

Metrick, A., and Weitzman, M. L.,. 1998. Conflicts and choices in biodiversity preservation. Journal of Economic Perspectives, 12, 21- 34.

McMahon, G., Gregonis,S.M., Waltman,S.W., Omernik,J.M., Thorson,T.D., Freeouf, J.A., Rorick, A.H., Keys, J.E., 2001. Developing a Spatial Framework of Common Ecological Regions for the Conterminous United States. Environmental Management. 28, 293-316. 
Noss, R.F., 1996. Ecosystems as conservation targets. Trends in Ecology And Evolution. 11, 351.

Omernik, J. M., 1995. Ecoregions: A Spatial Framework for Environmental Management. In: W. Davis and T. Simon (Editors), Biological Assessment and Criteria: Tools for Water Resource Planning and Decision Making, Lewis Publishers, Boca Raton, Florida, pp.49-62.

Omernik, J. M., 2003. The misuse of hydrologic unit maps for extrapolation, reporting, and ecosystem management. Journal of the American Water Resources Association. 39, 563-573.

Overton, J.McC., Leathwick, J.R., and Lehmann, A., 2000. Predict first, classify later -a new paradigm of spatial classification for environmental management: a revolution in the mapping of vegetation, soil, land cover, and other environmental information. 4th International Conference on Integrating GIS and Environmental Modelling (GIS/EM4), Canada (http://www.Colorado.EDU/research/cires/banff/upload/80/).

Patterson, B.D., Stotz,D.F., Solari,S., Fitzpatrick, J.W., and Pacheco, V, 1998. Contrasting patterns of elevational zonation for birds and mammals in the Andes of Southeastern Peru. Journal of Biogeography. 25, 593-607.

Pressey, R.L., Watts, M.E., and Barrett, T.W ., 2004. Is maximizing protection the same as minimizing loss? Efficiency and retention as alternative measures of the effectiveness of proposed reserves. Ecology Letters. 7, 1035-1046.

Potter, C., Tan, P.N., Steinbach, M., Klooster, S., Kumar, V., Myneni, R., and Genovese, V., 2003. Major disturbance events in terrestrial ecosystems detected using global satellite data sets. Global Change Biology. 9, 1005-21.

Reed, B.C., Brown, J.F., VanderZee, D., Loveland, T.R., Merchant, J.W., Ohlen, D.O., 1994. Measuring phenological variability from satellite imagery. Journal of Vegetation Science. 5,703-714.

Rignot, E., Salas,W. A., and Skole, D. L., 1997. Mapping deforestation and secondary growth in Rondonia, Brazil using imaging radar and Thematic Mapper data. Remote Sensing of Environment. 59,167-176. 
Rosenzweig, M.L., 1995. Species diversity in space and time. Cambridge: Cambridge University Press.

Rowe, J.S., and Sheard, J.W., 1981. Ecological land classification: a survey approach Environmental Management. 5, 451-464.

Running, S. W., Loveland, T. R., and Pierce, L. L., 1994. A vegetation classification logic based on remote sensing for use in global scale biogeochemical models. Ambio. 23, 77-81.

Schwartz, C.C., Haroldson, M.A., White, G.C., Harris, R.B., Cherry, S., Keating, K.A., Moody, D. and Servheen, C., 2006. Temporal spatial and environmental influences on the demographics of grizzly bears in the Greater Yellowstone Ecosystem. Wildlife Monographs. 161, 1-68.

Soriano and Paruelo, 1992. Biozones: vegetation units defined by functional characters identifiable with the aid of satellite sensor images. Global Ecology and Biogeography Letters. 2, 82-89.

Spies, T.A., and Turner, M.G., 1999. Dynamic forest mosaics. In M.L., Jr, Hunter (Editor), Maintaining biodiversity in forest ecosystems. Cambridge: Cambridge University Press, 95-160.

Stoms, D.M., Hargrove, W.W., 2000. Modeling potential NDVI to monitor environmental stress. International Journal of Remote Sensing. 21, 401-407.

Turner, W., Spector, S., Gardiner, N., Fladeland, M., Sterling, E., Steininger, M., 2003. Remote Sensing for Biodiversity Science and Conservation Trends. Ecology and Evolution. 18, 306-14.

Walker, P.A., and Cocks, K.D., 1991. HABITAT: a procedure for modeling a disjoint environmental envelope for a plant or animal species. Global Ecology and Biogeography Letters. 1, 108-118.

Walker, R.E., Stoms, D.M., Etes, J.E., and Cayocca, K.D., 1992. Relationships between biological diversity and multi-temporal vegetation index data in California. Technical Papers of the 1992 Annual Meeting of ASPRS/ACSM, Albuquerque, New Mexico, 3-7 March, Bethesda, MD. American Society for Photogrammetry and Remote Sensing. 562-71. 
Wang, Z., Zeng,Z., Barlage, M., Dickinson,R. E., Gao F., 2004. Using MODIS BRDF/albedo data to evaluate global model land surface albedo. Journal of Hydrometeorology. 5, 3-14.

Wiken, E. B., Compiler, 1986. Terrestrial Ecozones of Canada Ecological Land Classification Series No 19. Environment Canada, Hull Que, 26 pp and map.

Willig, M.R., Kaufman, D.M., and Stevens, R.D., 2003. Latitudinal gradients of biodiversity: pattern, process, scale and synthesis. Annual Review of Ecology and Systematics. 34, 273-309.

Yang, W., Huang,D., Tan,B., Stroeve,J., Shabanov,N. V., Knyazikhin,Y., Nemani,R., and Myneni, R. B., 2006. Analysis of Leaf Area Index and Fraction of PAR Absorbed by vegetation products from the Terra MODIS Sensor: 2000-2005. IEEE Transactions on Geoscience and Remote Sensing. 44, 1829-1842.

Zhang, T., R. Ramakrishnon and M. Livny. (1996). BIRCH: An efficient data clustering method for very large databases. Proceedings of the ACM SIGMOD Conference on Management of Data.p. 103-114, Montreal, Canada 


\section{LIST OF TABLES AND FIGURES}

Table 1: A summary of the characteristics of the three suites of indicators derived from remote sensing technologies, utilise by the regionalization.

Table 2: A description of the 15 terrestrial "ecozones" which form the broadest of the Environment Canada classification.

Table 3: The 10 most unique clusters as defined from the regionalization and the relative ranking of the remotely sensed derived indicators.

Table 4: Description of the 14 derived cluster and the relative rank of the remotely sensed indicators.

Figure 5: Relationship between the derived clusters and the existing 15 class Environment Canada ecozone classification.

Figures 1: The three remotely sensed indicators used in the regionalization (a) Land cover, (b) the Dynamic Habitat Index (DHI) and (C) terrain. Figure 1(d) shows the existing 14 class ecozones derived by Environment Canada for reference.

Figure 2: The results of the clustering analysis from the initial 100 pre-clusters, to the 40 , and 14 cluster levels is diagrammatically shown as a dendogram.

Figure 3: Map of the 10 most unique clusters across Canada defined as the 10 clusters with the largest distances to any neighbouring clusters.

Figure 4: Four maps of the 14 clusters derived from the regionalization; (a) All clusters, (b) Cluster $1-5$, (c) Cluster 5-10, and (d) Cluster $11-14$. 